\title{
Stefan Huebner
}

Pan-Asian Sports and the Emergence of Modern Asia, 1913-1974. Singapore: NUS

Press, 2016, xiv + 397 pp. ISBN 9789814722032. Price: SGD 46.00 (paperback).

Stefan Huebner's Pan-Asian Sports and the Emergence of Modern Asia presents an important intersection of Asian studies and the history of sport, a welcome subject given the paucity of work on the evolution of embodied physical activity in Asia. Huebner chronicles the creation in 1913 and early iterations of the now-defunct Far Eastern Championship Games (FECG), the only instance, in Delhi in 1934, of the Western Asiatic Games, and the first seven iterations of the Asian Games (1951-1974). This periodization bookends the emergence of Asian-hosted multi-sport, Olympic-style events, from the FECG to the 1974 Asian Games in Tehran, which were the first hosted in Western Asia and the first to include athletes from Arab nations and the People's Republic of China.

In a narrative that proceeds chronologically, each chapter examines one or more of these particular Games: event organizers, their aims and ideals, the political context within which each games unfolded, the investment in the attendant facilities and infrastructure, and the symbols and ceremonies on display in locations as diffuse as Tokyo to the east, Jakarta to the south, and Tehran to the west. Such geographic latitude plus the ideological diversity of participating nations highlight the challenge of communicating any consensus of "pan-Asianness."

Huebner emphasizes the mass participation narrative of the FECG, instigated as they were by Western YMCA leaders based in East Asia. Historians of sport have explored the ways in which nineteenth-century notions of amateur sport were cloaked in what has been labelled "rational recreation," put to instrumental ends, often in the service of creating disciplined, Christian subjects ("muscular Christianity"), and exported as part of Western colonial projects. Huebner frames the FECG, which were the brainchild of American YMCA leaders (primarily Elwood Brown) and first held in the Philippines, as a pursuit of "egalitarian internationalism" through sport. He notes the ways in which organizers celebrated being able to bring together Filipino, Chinese, and Japanese athletes. Many sport leaders, including the Asian-born physical educators who took over the organization from Brown and his colleagues, had ties to the West and promoted particularly Western sporting values, through their educational backgrounds, their work with organizations like the YMCA, and for some their eventual association with the Olympic movement.

Nevertheless, engendering a pan-Asian unity through sport proved elusive. For the initial Asian Games in 1951, organizers selected a motto in English and "Western songs that were foreign to all Asian countries" (p. 121). Despite some

(C) RUSSELL FIELD, 2016 | DOI: 10.1163/22134379-17204015

This is an open access article distributed under the terms of the Creative Commons 
early consensus among organizers, events began to reflect the varying nature of hosts, including Japan ("Asia's most developed country" [p. 228]), nascent democracies, and military dictatorships. The Asian Games were especially embroiled in Cold War politics. The Games hosted in Manilla and Bangkok adopted pro-Western positions (and essentially excluded communist regimes in the region), while the rhetoric surrounding the Asian Games in Jakarta and Tehran reflected Soviet and Chinese influence and an anti-colonial sensibility.

Huebner argues that despite the regional rhetoric the organizers of each of event had particular domestic goals. Increasingly, hosting the Asian Games became a rationale for modernization projects and assertions of national progress, and at times for host cities to realize development while asserting their centrality over wider regions (as was the case with Jakarta in 1962). These different Games evolved from a desire, among Western organizers, to promote "egalitarian internationalism" and construct a pan-Asian unity or sensibility to local hosts using them "for nation-branding purposes by showing national achievements and cultural authenticity both to the population and to an international audience" (p. 200). This pattern is similar to the changing nature of such events in the West at the same time, so that the focal point becomes Huebner's centering of Asian sport leaders in this process.

The FECG was dismissed in one American diplomatic report as "simply an athletic event" (cited on p. 72) and when the association that hosted the FECG dissolved in the mid-1930s "almost no one cared" (p. 73). Such claims are significant when, despite the lofty goals of Brown and the YMCA's international leaders, we acknowledge that the FECG never attracted more than 500 participants. The challenge for historians, especially those who study sporting events, is to demonstrate the ways in which these events are embedded within larger cultural processes and geopolitical tensions, rather than "just" sport. The contribution that Huebner makes is reminding us that sport does matter, especially as it played a role throughout Asia, in varying ways, in the progress towards decolonization and the assertion of national identity and modernization through sport.

Russell Field

University of Manitoba russell.field@umanitoba.ca 